\title{
How much does the Level of Physical Activity Change in Patients with Physical Disabilities Hospitalized for Rehabilitation?
}

\section{Rehabilitasyon İçin Hospitalize Edilen Fiziksel Engelli Bireylerde Fiziksel Aktivite Düzeyi Nekadar Değişiyor?}

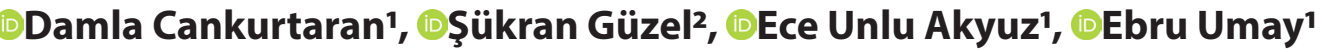 \\ 'Health Sciences University Diskapi Yildirim Beyazit Training and Research Hospital, Department of Physical Medicine and Rehabilitation, \\ Ankara, Turkey \\ 2Baskent University, Faculty of Medicine, Physical Medicine and Rehabilitation Clinic Ankara Hospital, Ankara, Turkey
}

\begin{abstract}
Objective: This study aimed to examine the short term effect of inpatient rehabilitation program on self-reported physical activity in participants with physical disabilities.
\end{abstract}

Material and Method: The patients were divided into groups as group 1: individuals with physical disability due to musculoskeletal diseases, and group 2: individuals with physical disability due to neurological diseases. The results of Physical Activity Scales for Individuals with Physical Disabilities (PASIPD) at one month after discharge (PA2) compared with the results of PASIPD at hospitalization (PA1). The first assessment was done face-to face, but the assessment after discharge were made using phone.

Results: There was a significant difference between PA2 and PA1 in group 1 , group 2 , and among all participants $(p=0.001)$. The change in physical activity level from hospitalization to one month after discharge was similar in the two groups $(p=0.564)$.

Conclusion: While people learn to live with a disability, quickly integrating physical activity with rehabilitation program into their new daily routine can be seen as a good strategy.

Keywords: disability, physical activity, rehabilitation, televisit
Öz

Amaç: Mevcut çalışmada fiziksel engelli bireylerde hospitalize edilerek uygulanan rehabilitasyon uygulamalarının kısa dönem etkisinin değerlendirilmesi amaçlanmıştır.

Gereç ve Yöntem: Hastalar grup 1: kas-iskelet sistemi hastalıkları nedeniyle fiziksel engelli bireyler ve grup 2: nörolojik hastalıklar nedeniyle fiziksel engelli bireyler olarak gruplara ayrildı. Hospitalizasyonlarının ilk günündeki Fiziksel Engelli Bireyler için Fiziksel Aktivite Ölçek (FEBFAÖ) sonuçları (FA1) taburculuktan bir ay sonraki ile (FA2) karşılaşıııılmıştır. Illk değerlendirme yüz yüze yapıldı ancak taburcu olduktan sonraki değerlendirme pandemi nedeniyle telefon aracilığılla yapıldı.

Bulgular: Grup 1'deki, grup 2'deki ve tüm katılımciların FA2 ve FA1 arasında anlamlı fark vardı $(p=0,001)$. I ki grup arasında fiziksel aktivite düzeyinin değişimi açııından anlamlı fark saptanmadı $(p=0,564)$.

Sonuç: İnsanlar fiziksel bir engelle yaşamayı öğrenirken, fiziksel aktiviteyi rehabilitasyon programıyla hızlı bir şekilde yeni günlük rutinlerine entegre etmek iyi bir strateji olarak görülebilir.

Anahtar Kelimeler: disabilite, fiziksel aktivite, rehabilitasyon, televisit

Corresponding (illetişim): Damla Cankurtaran, M.D., Department of Physical Medicine and Rehabilitation, University of Health Sciences Diskapi Yildirim Beyazit Training and Research Hospital, Ankara, Turkey

E-mail (E-posta): damlacengizftr@gmail.com

Received (Geliş Tarihi): 20.05.2021 Accepted (Kabul Tarihi): 11.07.2021 


\section{INTRODUCTION}

The World health organization (WHO) describes physical activity as any body movement produced by skeletal muscles that results in energy expenditure in daily life activities above resting level..$^{[1]}$ The implications of physical inactivity on health has been the subject of many studies recently. ${ }^{[2]}$ An inactive lifestyle is accompanied by higher risks for morbidity and mortality of a great number of chronic diseases such as coronary artery disease, diabetes, colon cancer, and osteoporosis. ${ }^{[2,3]}$ Physical activity levels can be measured by accelerometers, pedometers, heart rate monitors and various types of questionnaires. ${ }^{[4]}$

Disability was defined by WHO as a restriction or lack of ability to perform daily activity, but this definition was later changed to problems in functioning in the WHO classification of Functioning, Disability and Health (ICF). ${ }^{[5]}$ Disability is used as an umbrella definition that includes 3 components of health: body functions and structures, activity limitations, and participation restrictions. ${ }^{[6]}$ Thirteen to $20 \%$ of the western population has one or more disabilities. ${ }^{[2]}$ Osteoarthritis, back pain, neck pain, rheumatologic diseases, neurologic disorders (stroke, spinal cord injury, multiple sclerosis, Parkinson diseases) can cause physical disabilities. ${ }^{[3,6]}$ Recent studies have shown that; high levels of disability is related with low levels of physical activity. ${ }^{[3,7]}$ Also, compared to non-disabled individuals, it has been observed that disabled individuals do less physical activity in their leisure time and less physical activity of at least 30 minutes of moderate intensity five days a week. ${ }^{[2,7]}$ This result may not be surprising; environmental barriers, pain, embarrassment, transportation problems, inadequate accommodations, and unsuitable sports may be some possible barriers to physical activity for individuals with disability. ${ }^{[8,9]}$

Individuals with disability are commonly hospitalized in inpatients clinics for rehabilitation, which aims to achieve optimal functional level of patients within their own limitations. ${ }^{[10]}$ A rehabilitation program can be an excellent opportunity to integrate post-rehabilitation physical activity into their lifestyle. ${ }^{[1]]}$

In previous studies, the effect of structured outpatient rehabilitation program on physical activity, or the effect of inpatient rehabilitation program on only participants with neurological disorders like as: spinal cord injury were investigated. ${ }^{[2,12]}$

This study aimed to examine the short term effect of inpatient rehabilitation program on self-reported physical activity both participants with physical disabilities due to musculoskeletal and neurological disorders.

\section{MATERIAL AND METHOD}

\section{Study population and design}

This study was designed as a prospective cohort study in the physical medicine and rehabilitation (PMR) inpatients clinic.
This study was approved by the University of Health Sciences Dışkapı Yıldırım Beyazıt Training and Reserach Hospital Institutional Ethics Committee (Approval number: 94/06), and was conducted in accordance with the Declaration of Helsinki guidelines Signed informed consent was obtained from each participants prior to starting data collection.

Ninety-two patients with physical disabilities, due to neurologic or musculoskeletal diseases and hospitalized in PMR clinic for rehabilitation between September 2020 and March 2021 were included in this study. Twelve patients who could not be followed up at the end of the first month were excluded from the study and the study was completed with 80 patients.

Inclusion criteria were patients over 18 years of age with cognitive functions able to fill the forms and patients with medical stabilization for neurological diseases.

Patients under 18 years of age, patients with additional hearing, visual and mental disabilities, patients with metabolic instability for neurological diseases, history of malignancy and pulmonary and cardiac failure, and patients with recurrent hospitalization in the PMR clinic were excluded from the study.

\section{Demographic Data}

It includes demographic and disease characteristics including age, gender, job, marital status, and comorbidities, and diagnosis requiring hospitalization.

\section{Self-reported Physical Activity Measure}

The physical activity scale for individuals with physical disabilities (PASIPD) was used to evaluate the physical activity level of the patients. The PASIPD was developed by Washburn et al. ${ }^{[13]}$, and consists of 13-items: 6 leisure time, 6 households, and 1 occupational activity item. The number of days participated in these activities in the past 7 days was asked as never, seldom (1-2 d/week), sometimes (3-4d/week), or often (5-7 d/week) and the average of how many hours a day they participated $(<1$ hour, $>1$ but $>2$ hour, $2-4$ hour, $>4$ hour $)$. The response to the occupational item was categorized as $<1$ hour, $>1$ but $<4$ hour, $>5$ but $<8$ hour, $>8$ hour. The score for each item was found by multiplying a MET value associated with the activity intensity using the daily average hours for each item, and the total score was obtained by adding the scores of the items between 2-13. The first item, which requests information about sedentary life, wasn't scored.

\section{Interventions}

At the first day of hospitalization, all participants were examined by the same physiatrist. After that, a rehabilitation program was planned for each patient according to the current functional status of these patients. Rehabilitation programs included two or more electrotherapies, heat treatments, stretching-strengthening exercises, walkingbalance exercises, sitting exercise and transfer training one session/a day, 5 days/week during 4 weeks. The intensity of physical therapy and duration of hospitalization were determined according to the age, disease, functional status, comorbidities, and secondary complications of each patient. 
The patients were divided into groups as group 1: individuals with physical disability due to musculoskeletal diseases, and group 2: individuals with physical disability due to neurological diseases the participants in both groups were evaluated two times (PA1, PA2). The first assessment (PA1) was made on the second day of hospitalization, the second assessment (PA2) one month after discharge. At the first evaluation, demographics (age, gender, job, comorbidities...), diseases characteristics, and the level of self-reported physical activity were examined. The first assessments was done face-to face, but the assessment after discharge were made by telephone (Figure 1).

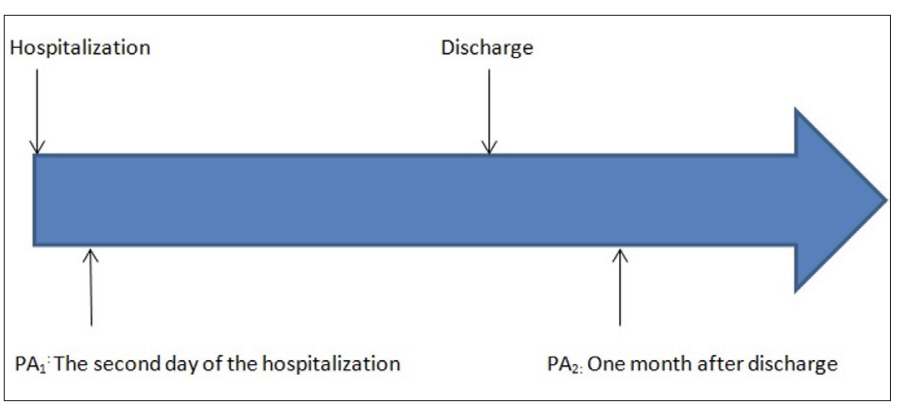

Figure 1. Study Protocol

\section{Comparisons}

The changes in PASIPD scores were compared between groups, within groups, and among all participants.

\section{Statistical Analyses}

The data analyses were conducted using Statistical Package for the Social Sciences (SPSS 22.0 for Windows) software. The variables were investigated using visuals (histograms, probability plots) and a Kolmogorov-Smirnov test. In reporting descriptive statistics, data were expressed as mean \pm standard deviation (SD) and median (minimum-maximum) for continuous variables, and as frequencies and percentages

(\%) for nominal and categorical variables. PA2 and PA1, were compared with Wilcoxon signed rank test in group 1, group 2 , and among all participants. The $x^{2}$ tests and Fisher's exact tests were used to compare nominal and categorical variables as well as the independent sample $T$ and Mann-Whitney $U$ tests were used to compare the continuous values between group 1 and 2 . A p-value of $<0.05$ was considered statistically significant.

\section{RESULTS}

The mean age of all patients was $60.76 \pm 15.71$ years, $48(60 \%)$ were female and $32(40 \%)$ were male. Half of the patients (group $1, \mathrm{n}=40$ ) had musculoskeletal diseases and the other half (group 2, $n=40$ ) had neurological diseases. Demographics and disease data of the patients are shown in Table $\mathbf{1}$ and Table 2.

According to the results comparing the demographic characteristics of the two groups, there was no significant difference in age, job, marital status and comorbidities $(p>0.05)$. The gender of the participants in group 1 was significantly different from group 2 ( $p=0.006)$.

At the beginning of the hospitalization participants in group 1 had higher self-reported physical activity level comparing participants in Group $2(p=0.01)$. The PASIPD scores were statistical similar between two groups at the one month after discharge $(p>0.05)$.

\section{Table 2. Disease data of patients}

Group 1 n=40, n(\%)

Rheumatoid arthritis 2 (5)

Gonarthrosis 4 (10)

IVD 24 (60)

Artroplasty 3 (7.5)

Shoulder problems 6 (15)

Anykilosing Spondylitis 1 (2.5)
Group 2 n=40, n(\%)

TBI 5 (12.5)

ALS 1 (2.5)

Stroke $21(52.5)$

GBS 4 (10.0)

Brachial plexus 1 (2.5)

Parkinson diseases 2 (5.0) SCI 6 (15.0)

IVD: intervertebral disc diseases, TBI: traumatic brain injury, ALS: amyotrophic lateral sclerosis, GBS: Guillain- Barre Syndrome, SCl: spinal cord injury

\begin{tabular}{|c|c|c|c|c|c|}
\hline & & Total $n=80$ & Group $1 \mathrm{n}=40$ & Group $2 \mathrm{n}=40$ & $\mathbf{P}$ \\
\hline \multicolumn{2}{|c|}{ Age (years) mean $\pm S D$} & $60.76 \pm 15.71$ & $63.26 \pm 17.66$ & $58.26 \pm 17.66$ & $0.16^{*}$ \\
\hline \multicolumn{2}{|c|}{ Gender n (\%) Female/Male } & $48(60) / 32(40)$ & $30(75) / 10(25)$ & $18(45) / 22(55)$ & $0.006^{* *}$ \\
\hline \multirow{3}{*}{$\begin{array}{l}\text { Job } \\
\text { n(\%) }\end{array}$} & Workman & $17(23.1)$ & $7(17.5)$ & $10(25.0)$ & \multirow{3}{*}{$0.09^{* * *}$} \\
\hline & Driver & $6(7.5)$ & $3(7.5)$ & $3(7.5)$ & \\
\hline & Student & $1(1.3)$ & 0 & $1(2.5)$ & \\
\hline \multirow{3}{*}{$\begin{array}{l}\text { Marital status } \\
\mathrm{n}(\%)\end{array}$} & Single & $7(8.8)$ & $1(2.5)$ & $6(15.0)$ & \multirow{3}{*}{$0.09^{* * *}$} \\
\hline & Divorced & $20(25.0)$ & $12(30.0)$ & $8(20.0)$ & \\
\hline & Married & $53(66.3)$ & $27(67.5)$ & $26(65.0)$ & \\
\hline $\begin{array}{l}\text { Comorbidities } \\
\text { n (\%) }\end{array}$ & $\mathrm{HT}$ & $50(62.5)$ & $26(65)$ & $24(60)$ & $0.65^{* *}$ \\
\hline
\end{tabular}


The change in PASIPD from hospitalization to one month after discharge was similar in the two groups $(p=0.564)$ (Table 3).

\begin{tabular}{|c|c|c|c|}
\hline & $\begin{array}{c}\text { Group 1, } \mathrm{n}=40 \\
\text { median (min-max) }\end{array}$ & $\begin{array}{c}\text { Group } 2, \mathrm{n}=40 \\
\text { median (min-max) }\end{array}$ & $p$ value \\
\hline PA1 MET h/day & $1.94(0-29.99)$ & $0.0(0-8.84)$ & 0.001 \\
\hline PA2 MET h/day & $7.31(0.49-54.92)$ & $5.83(0.93-19.18)$ & 0.138 \\
\hline PA2-PA1 MET h/day & $4.69(0 / 47.12)$ & $3.82(0.33 / 17.44)$ & 0.564 \\
\hline
\end{tabular}

There was a significant difference between PA2 and PA1 in group 1, group2, and among all participants $(p=0.001)$ (Table 4).

Table 4. Changes in self- reported physical activity of participants

\begin{tabular}{lcccccc} 
& $\begin{array}{c}\text { Group 1 } \\
\text { n=40 } \\
\text { median } \\
\text { (min-max) }\end{array}$ & p1 & $\begin{array}{c}\text { Group 2 } \\
\text { n=40 } \\
\text { median } \\
\text { (min-max) }\end{array}$ & p2 & $\begin{array}{c}\text { Total } \\
\mathbf{n = 8 0} \\
\text { median } \\
\text { (min-max) }\end{array}$ & p3 \\
\hline PA1 & 1.94 & & 0.0 & & 0.69 & \\
MET h/day & $(0-29.99)$ & 0.001 & $(0-8.84)$ & 0.001 & $(0-29.99)$ & 0.001 \\
PA2 & 7.31 & & 5.83 & & 6.66 & \\
MET h/day & $(0.49-54.92)$ & $(0.93-19.18)$ & $(0.49-51.92)$ & \\
\hline
\end{tabular}

Min-max: minimum-maximum, PA1: Physical activity level at one day after hospitalization, PA2: Physical activity level at one month after discharge, $\mathrm{p} 1$ shows comparison of PA1 and PA2 in group $1, \mathrm{p} 2$ shows comparison of PA1 and PA2 in group 2, 33 shows comparison of PA1 and PA2 in all patients. Wilcoxon signed rank test were used.

\section{DISCUSSION}

This study analyzed the impact of the rehabilitation program on self- reported physical activity levels of participants with physical disabilities. This study determined that the selfreported physical activity levels increased significantly from the onset of hospitalization to one month after discharge. These results were obtained both in patients with physical disabilities due to musculoskeletal diseases and in patients with physical disabilities due to neurological diseases. Although the self- reported physical activity levels of patients with physical disabilities due to musculoskeletal diseases were higher than patients with physical disabilities due to neurological diseases at the beginning of hospitalized, the improvement in selfreported physical activity from hospitalization to one month after discharge was similar in the two groups.

Exercising large muscle groups at a frequency of 3-5 times a week, for a period of 20-60 min (or multiple 10-min sessions), at an intensity of $40-70 \%$ heart rate reserve (HRR) was recommended by the American Colleague of Sport Medicine to persons with chronic conditions or disabilities (stroke, amputation, spinal cord injury...) in order to improve aerobic fitness. ${ }^{[14]}$ Different results have been obtained in studies investigating the aerobic effects of rehabilitation programs. $[10,14-16]$
Self-reported (subjective) or device-based (objective) measurements are the instruments that measure physical activity. PASIPD, which is a self-reported questionnaire, was used to investigate the physical activity levels in this study. The reliability and validity of PASIPD, comparable to a wellestablished self-reported questionnaire for healthy people, was demonstrated. ${ }^{[2,17]}$ Although there was a correlation between hip accelerometers and PASIPD with correlation coefficients varying between 02.23 and 0.30 , it was stated that it would not be correct to compare these two different methods. ${ }^{[2,17]}$

In our study, we investigated the effects of routine rehabilitation programs on the self- reported physical activities of participants with disabilities. All participants continued their rehabilitation program in the inpatients clinic, so the impact of the environment was standardized for all patients. One month after discharge, self- reported physical activity was improved with rehabilitation among all participants and in both groups. In order to make our second evaluation, we preferred to do it one month after discharged when the patients returned to their normal daily life, because PASIPD is generally a questionnaire that evaluates housework and leisure activities, we thought that the evaluation made during the hospitalization of the patients might lead to incorrect evaluations.

During pandemic, our methods of evaluation patient were changed as all our habits changed. We preferred televisit method which is made over telephone to evaluate the selfreported physical activity level of participants due to transfer problems and pandemic. ${ }^{[18]}$

In a randomized controlled study, weekly self-reported physical activity levels increased with home or communitybased exercise programs in women with mobility problems. ${ }^{[18]}$ In this study, the weekly self-reported physical activity level and fitness parameters at the onset and end of the study ( 28 weeks later) were evaluated in the intervention group. However, in the control group, the weekly self-reported physical activity level was not investigated. ${ }^{[19]}$ No significant difference was found between the intervention group and control group in fitness parameters such as weight, body mass index, peak heart rate, and blood pressure. ${ }^{[19]}$ Increased physical activity nine weeks after rehabilitation was examined in a multicenter study ${ }^{[11]}$ They divided the participants into 3 groups, including those who had one of the following diagnoses: amputation, stroke, neurologic disorders, back disorders, rheumatic related disorders, and whiplash. Only a routine rehabilitation program was applied to the first group, sport counseling was given in addition to the routine rehabilitation program during the rehabilitation sessions in the second group, and sport counseling was initiated for the third group after nine weeks of rehabilitation. PASIPD scores increased significantly only in the group of patients who continued sport counseling after the rehabilitation program compared to the beginning of the study. ${ }^{[11]}$ No difference was found between a routine rehabilitation program and a routine rehabilitation program that adds sport counseling. Similar results were obtained by 
extending the study to one year; only in the group where sports counseling was continued after rehabilitation, a significant increase was found in PASIPD after one year when compared to the beginning of the study. ${ }^{[20]}$

Zbogar et al. ${ }^{[12]}$ investigated the effect of structured therapy on physical activity in patients with paraplegia or tetraplegia due to spinal cord injury. They recorded physical activity through a self-reported questionnaire and with 2 realtime accelerometers worn on the dominant wrist or hip for ambulatory individuals. According to the results of this study, there was no significant change in self -reported physical activity from discharge to admission. However, physical activity evaluated by accelerometers was significantly increased.

Although there are similar results to our study in the literature, there are different results in the change of physical activity with rehabilitation. This may be attributed to the different patient spectrum involved and assessment method.

We found that the physical activity levels increased with in patients rehabilitation program, but the continuation of post-rehabilitation counseling services is important in order to increase physical activity for a longer time or to try to transform physical activity into a lifestyle.

Some potential problems underlying improving physical activity behavior after rehabilitation were found to include psychosocial problems, as well as several barriers such as health conditions, limited environmental opportunities, lack of time, lack of motivation, lack of money, lack of motivation, and transportation problems. ${ }^{[21]}$

The first limitation of our study was the short follow-up period. A longer follow-up period is necessary to assess how much we can integrate the physical activity of participants who have started living with disabilities into their daily life. The second limitation was that PASIPD was a subjective measure. The combination of objective and subjective measures of physical activity can increase the reliability of our results. Another limitation of our study was that the duration of disability, which may be a factor in changing physical activity, wasn't evaluated. Since our study was conducted during the pandemic period, the number of our participants remained limited due to the fact that hospitalization of patients was reduced in this period within the framework of pandemic conditions.

\section{CONCLUSION}

The rehabilitation program seemed to provide an important opportunity to start promoting a physically active lifestyle. While people learn to live with a disability, quickly integrating physical activity with rehabilitation program into their new daily routine can be seen as a good strategy. Beneficial ways to continue increasing physical activity after rehabilitation are counseling services and longer follow-up periods. Therefore, it is important to plan and structure rehabilitation activities in these patients according to psychosocial factors and environmental barriers in their daily lives.

\section{ETHICAL DECLARATIONS}

Ethics Committee Approval: This study was approved by the University of Health Sciences Dışkapı Yıldııım Beyazıt Training and Reserach Hospital Institutional Ethics Committee (Approval number: 94/06).

Informed Consent: All patients signed the free and informed consent form.

Referee Evaluation Process: Externally peer-reviewed.

Conflict of Interest Statement: The author(s) declared no potential conflicts of interest with respect to the research, authorship, and/or publication of this article.

Financial Disclosure: The authors declared that this study has received no financial support.

Author Contributions: All of the authors declare that they have all participated in the design, execution, and analysis of the paper, and that they have approved the final version.

\section{REFERENCES}

1. World Health Organisation. Organization, W.H., World Health Organization Step to Health: A European Framework to Promote Physical Activity for Health. 2015 [cited 2021 January 17]. Available from: www.who.int

2. Van der Ploeg HP, Van der Beek AJ, Van der Woude LH et al. Physical activity for people with a disability. Sports Med 2004;34:639-49.

3. de Hollander EL, Proper KI. Physical activity levels of adults with various physical disabilities. Prev Med Rep 2008;10:370-6.

4. Ulaş K, Topuz S, Horasan G. The validity and reliability of the Turkish version of the Physical Activity Scale for Individuals with Physical Disabilities (PASIPD). Turk J Med Sci 2019;49:1620-25.

5. Tatlı HU, Köseoğlu BF, Özcan DS et al. Validation and application of the international classification of functioning core set for spinal cord injury in the Turkish patients. Turk J Phys Med Rehabil 2019;65:244.

6. Lin CWC, McAuley JH, Macedo L et al. Relationship between physical activity and disability in low back pain: a systematic review and metaanalysis. Pain 2011;152: 607-13.

7. Van der Ploeg HP, Streppel KR, Van der Beek AJ et al. Successfully improving physical activity behavior after rehabilitation. Am J Health Prom 2007;21:153-9.

8. Bragaru M, Van Wilgen CP, Geertzen JH et al. Barriers and facilitators of participation in sports: a qualitative study on Dutch individuals with lower limb amputation. PloS one 2013;8: e59881.

9. Wright A, Roberts R, Bowman G, Crettenden A. Barriers and facilitators to physical activity participation for children with physical disability: comparing and contrasting the views of children, young people, and their clinicians. Disabil Rehabil 2019;41:1499-507.

10. Koopman AD, Eken MM, van Bezeij T et al. Does clinical rehabilitation impose sufficient cardiorespiratory strain to improve aerobic fitness?. J Rehabil Med 2013;45:92-98.

11. Van der Ploeg HP, Streppel KRM, Van der Beek AJ et al. Counselling increases physical activity behaviour nine weeks after rehabilitation. $\mathrm{Br} J$ Sports Med 2016;40: 223-29.

12. Zbogar D, Eng JJ, Miller WC, et al. Physical activity outside of structured therapy during inpatient spinal cord injury rehabilitation. J Neuroeng Rehabil 2016;13: 1-11.

13. Washburn RA, Zhu W, McAuley E et al. The physical activity scale for individuals with physical disabilities: development and evaluation. Arch Phys Med Rehabil 2002;83:193-200.

14. Durstine JL, Scott OR. ACSM's exercise management for persons with chronic diseases and disabilities. In:Geoffrey EM, Patricia LP, editors. Human Kinetics. Champaign, IL; 2016. 
15. Dallmeijer AJ, Van der Woude LH, Hollander PA et al. Physical performance in persons with spinal cord injuries after discharge from rehabilitation. Med Sci Sports Exerc 1999;31:1111-7.

16. Janssen TWJ, Van Oers CAJM, Veeger HEJ et al. Relationship between physical strain during standardised ADL tasks and physical capacity in men with spinal cord injuries. Spinal Cord 1994;32: 844-59.

17. van der Ploeg HP, Streppel KR, van der Beek AJ et al. The Physical Activity Scale for Individuals with Physical Disabilities: test-retest reliability and comparison with an accelerometer. J Phys Act Health 2007;4:96-100.

18. Pintaudi B, Garavaglia G, Disoteo OE et al. First televisits provided by the public health system for patients affected by diabetes mellitus in COVID-19 pandemic. Diabetes Res Clin Pract 2021;173:108697.

19. Froehlich-Grobe K, White GW. Promoting physical activity among women with mobility impairments: a randomized controlled trial to assess a home-and community-based intervention. Arch Phys Med Rehabil 2004;85:640-8.

20. Van der Ploeg HP, Streppel KR, Van der Beek AJ et al. Successfully improving physical activity behavior after rehabilitation. Am J Health Promot 2007;21:153-9.

21. van derPloeg HP, Streppel KR, van derBeekAJ, etal.Underlying mechanisms of improving physical activity behavior after rehabilitation. Int J Behav Med 2008:15:101-8. 